\title{
Entrepreneurship and Market Orientation: Mindset of Indigenous Community
}

\author{
Westim Ratang ${ }^{1} \quad$ Jhon Urasti Blesia ${ }^{2 *}$ \\ 1.Department of Management, Universitas Cenderawasih, Jayapura, Indonesia \\ 2.Department of Accountancy, Universitas Cenderawasih, Jayapura, Indonesia
}

\begin{abstract}
Wen Mina Hipere is a new method of agriculture, in this case, of farming sweet potatoes, modified by adding the cultivation of freshwater fish in the trench of the potato garden, practiced in several Dani tribe villages of Jayawijaya, one of Indonesia's regencies in West Papua. Training of these farmers, in entrepreneurship and market orientation is expected to create innovation and to motivate farmers with the entrepreneurial spirit. The research, therefore, aims to evaluate the changes to the mindset of Wen Mina Hipere farmers at pre-and post-training in entrepreneurship and market orientation. Fifty farmers in Wogi village, who have been engaged in the Wen Mina Hipere farming system, have been subject to research following their training in entrepreneurship and market orientation. The results show that the dominant change occurs in the growth of confidence in entrepreneurship, whereas they developed to a higher degree their sense of competition in the market orientation part of the training. In preserving this local wisdom, the related departments need to give intensive technical assistance, training and coaching to improve farmers' self-confidence, provide financial assistance and distribution channels for farmers to continue to perform within their traditional farming system.
\end{abstract}

Keywords: entrepreneurship; market orientation; Wen Mina Hipere; indigenous community.

DOI: $10.7176 / \mathrm{JMCR} / 57-02$

Publication date:June $30^{\text {th }} 2019$

\section{Introduction}

Food security is defined as a guarantee of access to the fulfillment of the food needs of every individual, in order for them to pursue a healthy life and perform various daily activities. Food insecurity, in contrast, is a condition of the lack of access to the food required for every individual. Rachman, Suhartini and Handono (2004) stated that insufficiency of food needs is influenced by food availability, distribution and access to the food.

Many agricultural economists have emphasized the importance of entrepreneurship for farmers, for instance, Smit, 2004; and Darmadji, 2012 explained that entrepreneurship in farmers is an important factor in determining the success of business that later leads to their food security. Bryant, 1989; Widodo and Nugroho 2008 added that entrepreneurship is important for farmers in the development of agribusiness. Hartono (2011) believed that through partnership programs, innovative and motivated farmers can possess and grow an entrepreneurial spirit.

Various opinions mentioned by agricultural economists, such as those mentioned above, both implicitly and explicitly emphasized the importance of entrepreneurship in agricultural activities for farmers. However, empirical evidence showing any existence of farmers' entrepreneurship is still rare. Therefore, this research is basically to confirm the role of farmers' entrepreneurship as a new alternative approach to increasing their performance. Using the system of Wen Mina Hipere in the Baliem valley of Jayawijaya, one of Indonesia's regencies in West Papua province, through an action research, this study will evaluate the effectiveness of the training to change the mindset of Dani's traditional farmers in entrepreneurship and market orientation to increase their performances.

\section{Literature Review}

\subsection{The concept of Entrepreneurship}

Most academic literature defines entrepreneurship as a process of doing something (creative), something different (innovative) and daring to take risk (risk-taking). A creative entrepreneur is understood to have the ability and tenacity to develop new ideas and combine all resources while always observing the current situation, to which they previously paid less attention (Schumpeter, 1934; Miller, 1983). In addition to determining various alternatives to a particular situation, the creative entrepreneur actively uses his unconscious mental and emotional powers to create new products or new methods to develop a product and so on. An innovative entrepreneur develops creative ideas (Quinn, 1979; 1985; Miller, 1983; Hamel and Prahalad, 1991; Covin and Slevin, 1991; Gonzalez-Benito, 2008) and dares to take risks in what he is doing, in order to get a chance to improve business and increase profit by taking advantage of opportunities and the potentiality of existing resources (Pinchot, 1987; Sykes and Block, 1989; Morris and Trotter, 1990). Gonzalez-Benito (2008) underlined the composite nature entrepreneurship by adding proactiveness as another key component which describes a pioneering behavior necessarily undertaken to face future contingencies and overcome the actions of competitors and this is highly supported by other researchers, such as Miller, 1983; Morris and Paul, 1987; Covin and Slevin, 1989; Miles and Arnold, 1991; Naman and Slevin, 1993; Kemelgor, 2002. 
Thornberry (2003) stated that, in describing high orientation of entrepreneurship, a business has an excellent value in various dimensions. In this orientation, a business needs to perform in such a way as to increase excellent value by applying the principles of speed, flexibility, focus, friendliness, frugality, and of being far-reaching and futuristic. Other entrepreneurship models addressed by Lumpkin and Dess (1996) emphasize autonomy, innovation, willingness to take risks, being proactive and possessing competitive aggressiveness.

Previous research about entrepreneurship indicates a direct relation between entrepreneurship orientation and the performance of the firms. Boso (2013) found that high level of both entrepreneurship and market orientation can maximize the performance in entrepreneurial firms operating in a less developed economy, Ghana. Nasution (2010) undertaking research in small and medium-size hotels in Indonesia believed that entrepreneurship and human resource management are considered as the most significant drivers of innovation and customer value. The result further suggested that the interaction between both entrepreneurship and market orientation have significant impact respectively on customer value and innovation. This result is in line with Gonzalez-Benito (2008) that confirm a strong relationship between entrepreneurship and market orientation and both orientations demonstrate a strong relationship with the performance and is also supported by Christensen and Bower, 1996; Slater and Narver, 1995; Atuahene-Gima and Ko, 2011.

Not much research is conducted for entrepreneurship for farmers. Schiebel (2002) trying to define rural entrepreneurs using both personality traits and characteristics with 881 farmers in Austria found that around 10\% of sample have a combination of personality traits that corresponded to those required for entrepreneurial activity and this study was previously performed by Hanf and Muller, 1997 and Peura et al, 2002. The same studies with same purpose are also performed by Vesala and Peura, 2002; Alsos et al, 2003.

Schiebel (2002) showed that three success factors of entrepreneurs are locus of control of reinforcement, problem-solving abilities and social initiative. This is supported by Carter, 1998; Carter and Rosa, 1998; McNally, 2001; Borsch and Forsman, 2001 who studied the position of management and business capability and the extent to which farmers are entrepreneurial suggested that the methods used to analyze business entrepreneurs in other sectors can be applied to farmers. However, entrepreneurship orientation for farmers are not found in the previous studies.

\subsection{The concept of Market Orientation}

Market orientation has an important role in retaining customers and taking a competitive position. Entrepreneurs who survive and successfully attract new customers will affect the market share of their business. In addition, the real profitability is gained through strong market orientation and high customer satisfaction. Keeping and maintaining the customers, therefore, should be the top priority in a market-based management, because satisfied customers constitute the key to profitability for the business.

Sanginga, et al. (2004) explained that market orientation has three management characteristics, namely, 1) Customer focus or an obsession to get to know and understand customers' needs and provide maximum satisfaction to them; 2) Competitor orientation or, on an ongoing basis, to continuously identify the strengths of competitors' resources and their marketing strategies; 3) A team approach or the use of cross-functional groups, all dedicated to developing and providing solutions for customers. This is in line with Narver and Slater (1990) who stated that that market orientation consists of three behavioral components - customer orientation; competitor orientation; and interfuctional coordination; as well as two decision criteria - long term focus and profitability. Jaworski and Kohli (1990) defined market orientation as organization-wide generation of market intelligence pertaining to current and future customer needs; dissemination of the intelligence across departments; and organization-wide responsiveness to it whereas their study was tested for validity of its market orientation construct by Cadogan et al,1999; 2002; Li and Zhou, 2010.

Slater and Narver (1995) then argued that market orientation is the principle cultural foundation of the organization learning. In addition to Despande, Farley and Webster, 1993; Kohli and Jaworski, 1990; Narver and Slater, 1990 and Shapiro, 1988, they defined market orientation as the culture that put customer as the highest priority on the profitable creation and maintenance while still considering the interests of other stakeholders and provides norms for behaviour in relation to the development of organization and responsiveness to market information. They later provided a definite relationship between the dimension of entrepreneurship and the component of market orientation with respect to being proactive in meeting the needs of customer and the competition, innovative and able to implement the strategic response entailing some degree of risk and uncertainty.

Boso (2012) in their research stated that high market orientation in addition to high entrepreneurship orientation are instrumental in enhancing business' success most effectively in a less developed economy. This is also in line with Hult and Ketchen (2001) that indicates that positional advantages from the confluence of market orientation with other important aspects of entrepreneurship, innovativeness and organizational learning positively affected return on investment, income and stock price of multinational corporations. Although Slater and Narver, 1995; Barrett abd Weinstein, 1999; Hult and Ketchen, 2001; Atuahene-Gima and Ko, 2001; Gonzales-Benito, 2008; Boso, 2012 believed that a market orientation, complemented by an entrepreneurial drive are strongly related 
to organizational success, Bhuian (2005) in utilizing structural equation model to test proposed model using 231 non-for-profit hospitals, on the other hand claimed the best combination of high-market/moderateentrepreneurship orientation indicating that market orientation is most effective when the hospitals maintain a moderate level of entrepreneurship orientation.

This literature review analyse the topic of market orientation which have been the subject of farmers' entrepreneurship, however, very limited trend in the literature is found and need further studies.

\section{The Dani Tribe in the Baliem Valley of Jayawijaya}

The name "Dani" is a tribal name given by the outsiders in the early stages of a joint American and Dutch expedition in 1926. The original name of Dani is still not clear, however the records quoted from Le Roux's report stated that the word "Dani" is derived from Ndani in Moni language, which means "east toward the rising sun". Although the native Dani do not know what is the meaning of "Dani" and who gave the name of "Dani", society in the Baliem valley understands the meaning of "Ndani" to be "peace".

The Dani tribe is spread across the central plateau of the heart of Paradise island of Papua and lives at an altitude of about 1600 meters above sea level, with a population of \pm 60.000 people. Baliem valley is situated in the Jawajiya mountains and has been dubbed the great valley, and is about $15 \mathrm{~km}$ long, the widest section being about $10 \mathrm{~km}$. The valley is fed by the Baliem river, which rises on the slopes of the Jayawijaya mountains and then flows eastward. At $139^{\circ}$ east longitude, the river is banked and joins the Mamberamo river (West Papuans called this the "Amazon of Papua").

Baliem valley has an area of approximately $1200 \mathrm{~km} 2$ with a wet tropical climate. It is influenced by its altitude, with an average temperature of $17.5^{\circ} \mathrm{C}$ and an average rainfall of 152.42 days per year. Its humidity level is more than $80 \%$ while the wind blows throughout the year with the highest average speed of 14 knots/hour and the lowest $2.5 \mathrm{knots} /$ hour. The topography consists of broad valleys and high mountains, some of which are covered in snow, for example Trikora peak (4,750 m), Yamin peak (4,595m) and Mandala peak $(4,760 \mathrm{~m})$.

The Dani tribe adheres to a system of patrilineal kinship where the lineage is derived from a group of ancestors going back six or seven generations. The Dani have polygynous marriage, where a man can have several wives. The nuclear family lives in one dwelling unit called "Silimo" and one Silimo can consist of several members of the extended family. A Dani village consists of three to four Silimo, each inhabited by eight to ten families.

The Dani tribe always lives together and its members help each other. The society has a permanent system of cooperation and its members have always worked together to complete each task. In opening a new garden for example, men work on the land until it is ready for planting and women then plant it. Each plan to build a house is always preceded by a consultation usually led by an elder of the tribe (tribal chief), where the arrangement takes place at the request of the owner of the house. The arrangement is normally conducted in the men's home (called "honai") or sometimes in the front yard of the male clan of the home owner, and it discusses the location of the building, the division of tasks and the time needed in which to build.

\section{The System of Wen Mina Hipere}

The Dani tribe in the Baliem valley of Jayawijaya in West Papua preserves a local wisdom called "Wen hipere", which teaches the importance of maintaining the availability of sweet potato as a staple food as well as traditional culinary ingredients in each traditional ceremony, called "hekekit ikhhogo". The potency of sweet potato developed through the use of Wen Mina Hipere is quite strong. The sweet potato planting area in Jayawijaya is 13,120 ha producing 131,915 tons, while the potential of agriculture based on food crops is 4,251,058 ha. 


\section{Figure 1. Wen Mina Hipere Farming System}

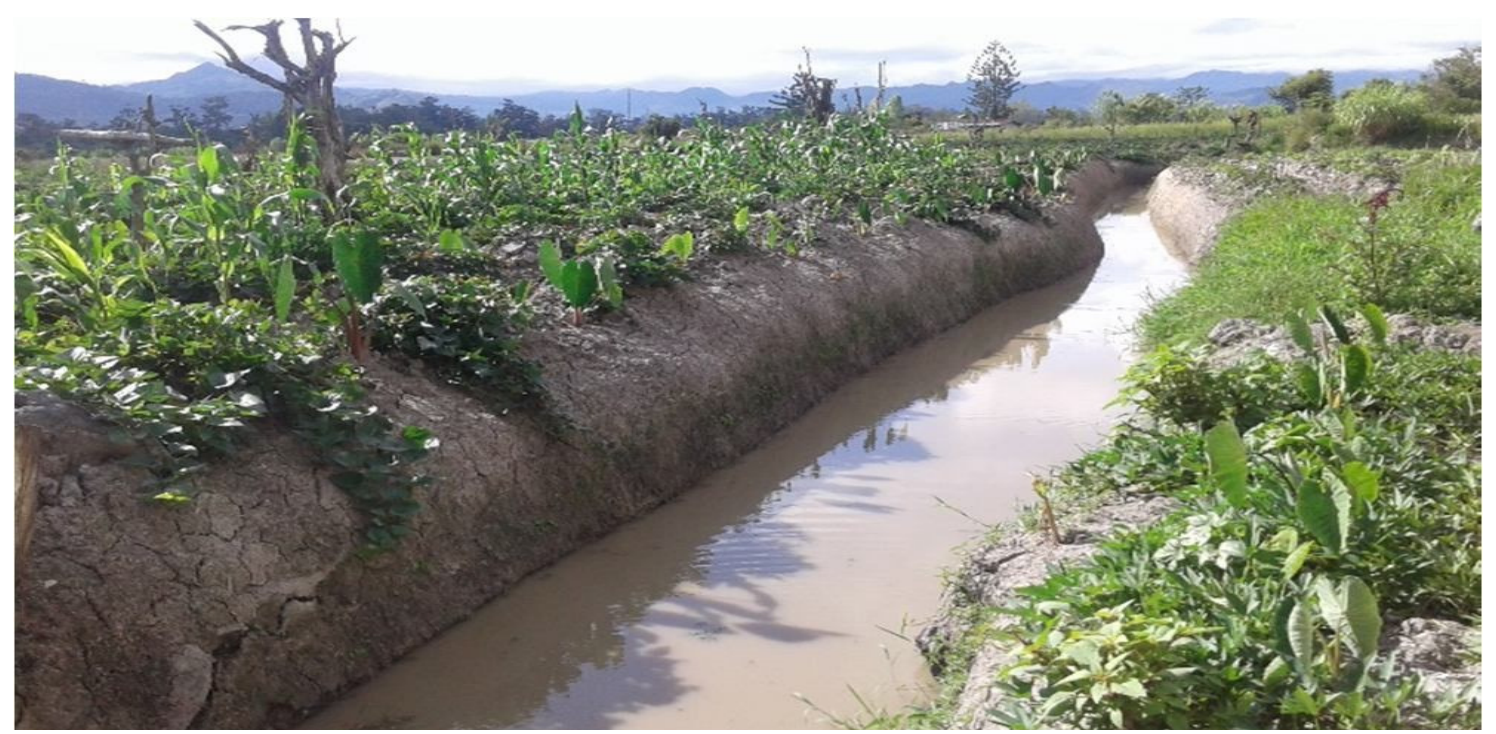

Wen Mina Hipere is a new method of agriculture in the Dany community. The system of sweet potato farming (hipere) that has developed in the Dani community is enhanced by the introduction of fish farming technology (mina) in the trenches of the potato garden. Wen Mina Hipere, modified through the construction of a large moat which acts as a barrier to the wild pigs, is technically qualified to grow freshwater fish while fish feed utilizes the leaves of sweet potato and cattle waste. Dual advantages obtained by the farmers are the increase in production of sweet potato and a source of protein from fish harvests.

Wen Mina hipere has grown in villages of Jayawijaya's five districts. Four villages in Assolokobal district are Hulekaima, Poteikeima, Uwanikaima and Wekiat villages, along with Musakfak village in Musakfak district. Other villages, such as Kepiatnem and Kulegaima villages in Hubikosi district also use the system, and farmers in Wogi village in Silokarno Doga district and Kumina village in Kurulu district have also practised this system. This system is expected to spread more widely to all plantations of sweet potatoes with similar soil conditions in the whole of the Baliem valley.

To accelerate the adoption of this new system, a non-government organization based in Baliem valley has approached the farmers through their traditional leaders, and provided them with facilities and intensive assistance to run Wen Mina Hipere farms. The implementation of this Wen Mina Hipere farming system is also likely to be developed into a system oriented to agribusiness. It is supported by the wider opening of the market opportunities in line with the development of the tourism industry in Baliem valley, which is one of the natural and cultural tourist destinations in Papua.

\section{Research Method}

The research is categorized as an action research engaging people in a systematic, data-driven process targeted to solve local problems. Key principles of an action research are given in its purpose, which is the development of an action for a specific issue where it is best addressed to those engaged in the research. This refers to the people who affect and are affected by the actions' implementation, outcomes and subsequent revision Goldstein, et al. (2016). The action research is performed to evaluate Wen Mina Hipere farmers' mindset after training in entrepreneurship and market orientation has been provided.

50 Wen Mina Hipere respondents in Wogi village, Silokarno Doga District are asked to participate in training of entrepreneurship and market orientation conducted over one week. Wogi village is chosen for the training of farmers due to its strategic location closer to the city of Jayawijaya. The entrepreneurship training is focused on improving important factors in entrepreneurship, such as, initiative, seeing opportunities, perseverance, searching for information, focus on work performance, commitment to the job, efficiency orientation, strategic planning, problem solving, self-confidence, persuasive ability, leadership strategies, and firmness. Market orientation training is concentrated on three important aspects, such as customer orientation, competitor orientation and inter functional coordination.

Wen Mina Hipere farmers competed pre-and post-survey about their attitude and experiences, after training has been given. They also participated in focus group discussions and unstructured interviews about their experiences with this farming system. Underlying the training design is the belief that entrepreneurship and market orientation are not innate to the people, but rather are learned. Farmers can develop certain orientation towards entrepreneurship and market orientation from training, sharing with others, as well as with their family and with 
other communities in their environment.

The collected data from pre-and post-survey about the given training are analyzed using confirmatory factor and frequency analyses to determine the change in farmers' mindset before and after entrepreneurship and market orientation training. The pre-and post-survey posed a total of 104 attitudinal statements, with eight designated to address thirteen factors in the entrepreneurship orientation, while 24 statements addressed three factors in the market orientation. The survey used a 5-point response scale, ranging from 1 indicating low $/ \mathrm{bad} / \mathrm{never}$ to 5 indicating high/good/always. Thompson (2004) stated that confirmatory factor analysis is used to confirm whether the latent factors are statistically reliable. Observations, unstructured interviews and focus group discussions about their farming experiences are conducted with a purposive sample method, so as to capture farmers' experiences in running the Wen Mina Hipere farming system.

\section{Findings}

6.1 Mindset of Farmers Pre-and Post-Training of Entrepreneurship Orientation

Wen Mina Hipere farmers are a group from the Baliem valley, the majority of whom have blood ties, from the elderly to children or children-in-law, and no other tribes can join them. This fact creates no conflict among groups as the group of families share the same characteristics and culture. Previously the groups were just trying to meet daily needs in the running of their farms, and did not have better orientation to develop the farming and utilize the harvest of potatoes and fresh water fish from the farm. Due to the remoteness of the area, which causes difficult access to the main town and the very low level of the community's intelligence, there has been growing marginalization of indigenous people in the village.

\section{Figure 2: Entrepreneurship and Market Orientation Training}

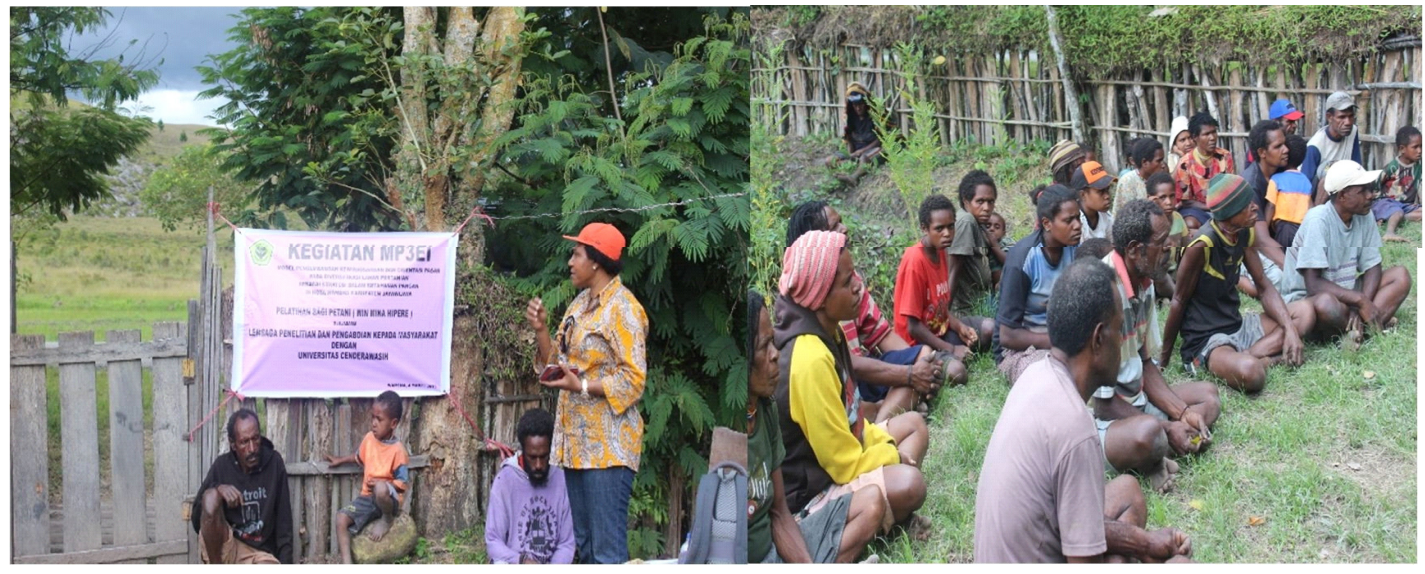

Training of entrepreneurship orientation includes the development of the initiative aspect, and it is shown that prior to the training, farmers have low initiative, especially in developing an idea and trying new things. After training of entrepreneurship is provided, the farmers' mindset changed. The factor of their ability to see opportunities also indicates that farmers can come to recognize opportunities to gain more profit by selling crops and that they intend to maintain as well as increase the harvest. Observation and focus group discussion concluded that farmers have marketed their harvest, both potatoes and fish, to the traditional market. 
Figure 3. the change of farmers' mindset in entrepreneurship factors

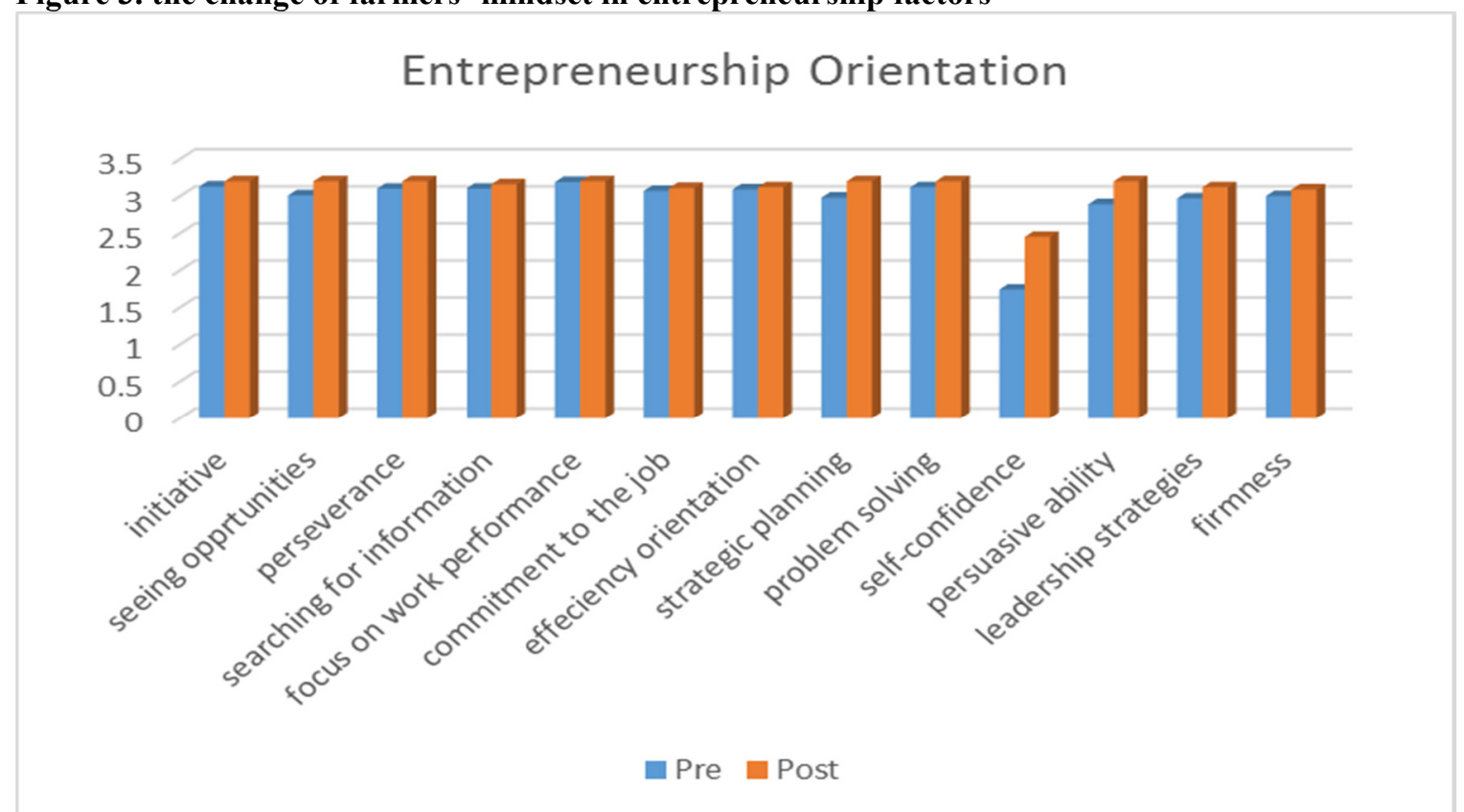

The training has also affected other factors, such as perseverance, searching for information, focus on work performance, commitment to the job, efficiency orientation, strategic planning, problem solving, self-confidence, persuasive ability, leadership strategies, and firmness. As for the perseverance aspect, pre-and post-survey in addition to focus group discussion and unstructured interviews shows that some farmers can now recover quickly and do not feel disappointed when facing failure, and that they are more diligent in completing the work. A change in searching for information is shown by farmers' attitude toward seeking information from the Department of Agriculture and Fisheries related to the agriculture potentiality and distribution channels. Farmers have actively asked for information from radio or other farmers.

Even though there have been many changes, the change in focus on work performance, commitment to the job, efficiency orientation and problem solving is relatively small. This indicates some change in mindset, however it is evident that more training should be provided. It differs from the strategic planning aspect, where farmers show the change in mindset by planning all processes of farming, including preparation of the land, planting, harvest and distribution.

Self-confidence shows a significant change, where farmers previously showed a lack of confidence, a feeling of anxiety, doubt and of often thinking negatively. After training is given, however, the farmers show more confidence and self-control in facing the problems, especially those occurring at the harvest time. In addition, the aspects of persuasive ability, leadership strategies and firmness show significant changes. Farmers show an ability to cooperate with other more advanced and experienced farmers, an attitude to share information with others and firmness in decision making and holding principles in their life.

6.2 Mindset of Farmers Pre-and Post-Training Market Orientation

Market orientation has three main indicators, such as customer orientation, competitor orientation and coordination with related agencies. The training is provided to teach farmers to focus on customers and competitors and on coordination with other related parties. The results show a considerable change in pre-and post-survey, in the attitude of farmers who actively search for information from other successful farmers. 
Figure 4. the change of farmers' mindset in market orientation factors

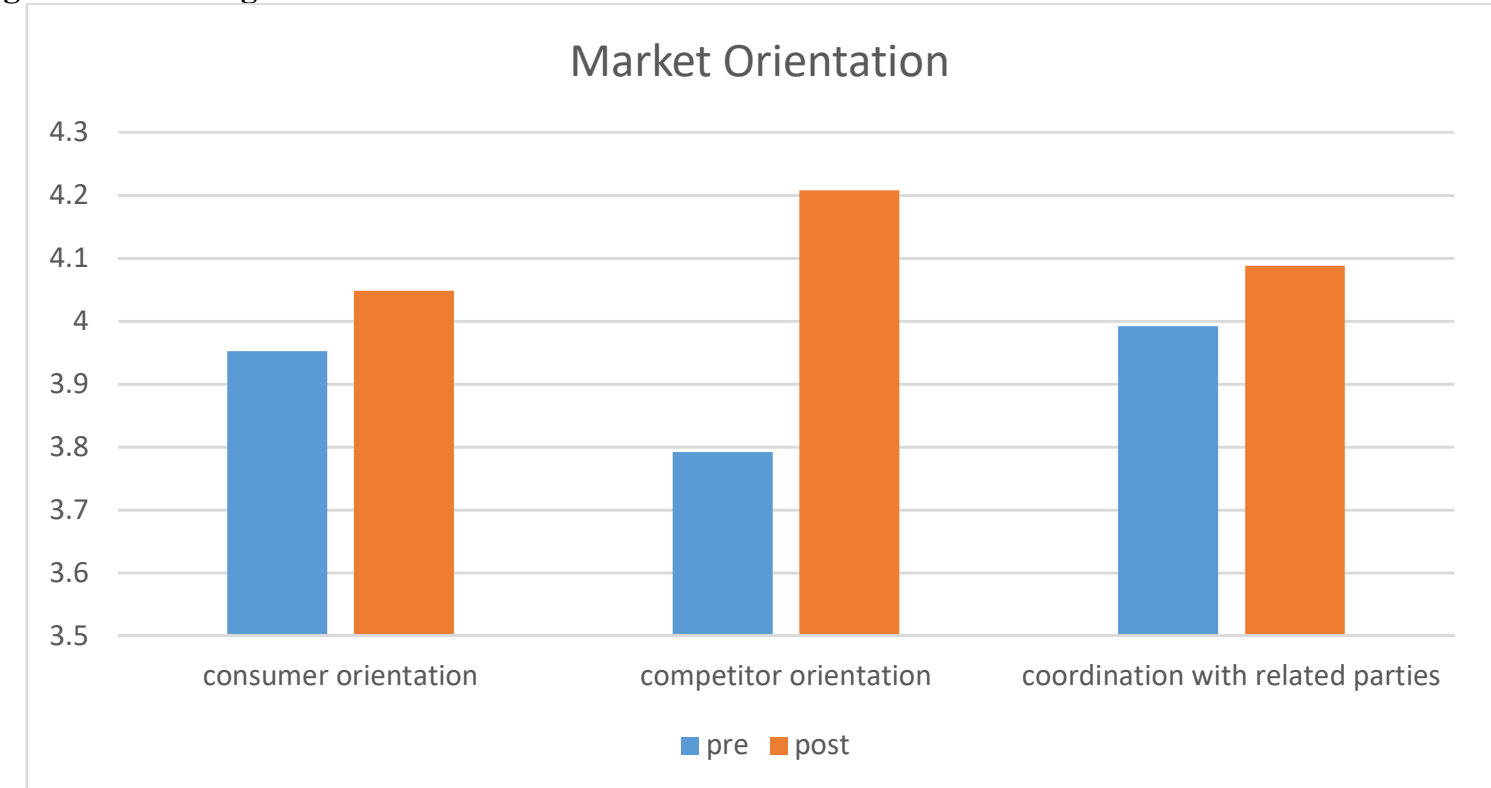

There is a change in the consumer orientation indicators, where previously farmers did not think to make any effort to change the crops to better value products, just waiting, instead, for government's financial assistance. After training of market orientation is introduced, farmers are trying to make value-added products, desired by consumers; for example, the production of potato chips with various flavors. The harvest of freshwater fish can also be made into salty fish and distributed to stores around the valley. Competitor orientation shows a significant change where, in the past, farmers consumed salty fish purchased from small stores from outside Papua with unclear quality, but where they now can produce their own salty fish for both daily consumption and marketing.

Coordination with related agencies also shows a considerable change, where farmers are now trying to seek updated information from the Department of Agriculture whether agricultural training is held, and where they now enquire whether they can obtain seeds and medicinal plants. The farmers also actively participate in agricultural activities provided by the Department of Agriculture in the regency of Jayawijaya.

\section{Conclusion}

Previous practices of Wen Mina Hipere farmers were simply aimed at trying to meet daily needs, and the farmers were not orientated towards future improvement. After the provision of entrepreneurship and market orientation training, farmers have shown changes in entrepreneurship and market orientation mindsets and are trying to achieve success. Most of the factors in the training have influenced the entrepreneurship capabilities of Wen Mina Hipere farmers, but the aspects of focus on work performance, commitment to the job, efficiency orientation, problem solving and firmness have relatively small impacts. The same changes occur in the variables of consumer orientation, competitor orientation and coordination with related agencies. Nevertheless, further work within this research remains limited. More work, therefore, needs to be conducted to capture more information about profitability or level of success, in order to evaluate the effectiveness of the training provided.

The relevant department, such as, the Department of Agriculture and Fisheries, needs to provide intensive assistance, training and coaching to improve the advancement of agricultural Wen Mina Hipere products and this includes financial assistance and distribution channels. Assistance also needs to be given to improve farmers' selfconfidence and spirit of success in order to successfully manage their agricultural products. Furthermore, as the region contains high potential tubers, such as cassava and taro, a similar process to that employed in the making of potato chips can also be applied to cassava and taro chips, which can be processed into a high quality and delicious snack. This will also grow the entrepreneurial spirit and the market orientation of the farmers in the area.

\section{Acknowledgements}

This research has been funded fully by the Higher Education of Indonesia. The content of this study does not necessarily reflect the views or policies of the Higher Education of Indonesia.

\section{References}

Darmadji. 2012. "Analysis of Farmers Entrepreneurship Analisis Kewirausahaan Petani." Malang Agrika (Program Studi Agribisnis Fakultas Pertanian Universitas Widyagama) 6 (1).

Goldstein, B.L, M Ick, W Ratang, H Hutajulu, and J.U Blesia. 2016. "Using the Action Research Process to Design 
Entrepreneurship Education at Cenderawasih University." Procedia-Social and Behavioral Sciences 228: 462-469.

Hartono. 2011. "Pendidikan Entrepreneurship: Upaya Peningkatan Kemakmuran dan Daya Saing Bangsa di Era Globalisasi."

Jaworski, Bernard, and Ajai Kohli. 1990. "Market Orientation: The Construct, Research Propositions and Management Implications.” Journal of Marketing 54: 1-18.

Lumpkin, G, and G Dess. 1996. "Clarifying the Entrepreneurial Orientation Construct and Linking it to Performance." Academy of Management Review 21 (1).

Narver, J.C, and S.F Slater. 1990. "The Effect of A Market Orientation on Business Profitability." The Journal of Marketing 20-35.

Rachman, Suhartini, and Handono. 2004. Prospek Ketahanan pangan Nasional (Analisis dari Aspek Kemandirian Pangan). Bogor: Pusat Analisis Sosial Ekonomi dan Kebijakan Pertanian.

Sanginga, P.C, R Best, C Chitsike, R Delve, S Kaaria, and R kirkby. 2004. "Enabling Rural Innovation in Africa: An Approach for Integrating Farmer Participatory Research and Market Orientation for Building the Assets of Rural Poor." Uganda Journal of Agricultural Science 9 (1): 942-957.

Thompson, B. 2004. Exploratory and Confirmatory Factor Analysis: Understanding Concepts and Applications. Washington, DC, US: American Psychological Association.

Thornberry. 2003. "Corporate Entrepreneurship: Teaching Managers to be Entrepreneurs." Journal of Management Development 22 (4): 329-344.

Widodo, and Nugroho. 2008. "Model Pendidikan Kewirausahaan Bagi Santri Untuk Mengatasi Pengangguran di Pedesaan." 